\title{
Incrimination of Anopheles (Anopheles) intermedius Peryassú, An. (Nyssorhynchus) nuneztovari Gabaldón, An. (Nys.) oswaldoi Peryassú as natural vectors of Plasmodium falciparum in French Guiana
}

\author{
Isabelle Dusfour $/{ }^{+}$, Jean Issaly, Romuald Carinci, Pascal Gaborit, Romain Girod \\ Unité d'Entomologie Médicale, Institut Pasteur de la Guyane, 23 Av. Pasteur, \\ 97306 Cayenne Cedex, Guyane Fançaise
}

Anopheles darlingi Root is the major vector of human malaria in the Neotropics and has been considered to be the sole malaria vector in French Guiana. The presence of other potential vectors suggests that malaria may be transmitted by other species under certain conditions. From 2006-2011, all anopheline specimens collected from 11 localities were assayed to determine if the Plasmodium circumsporozoite protein was present. In addition to An. darlingi, we found Anopheles oswaldoi, Anopheles intermedius and Anopheles nuneztovari specimens that were infected with Plasmodium sp. Further investigations on the behaviour and ecology of An. oswaldoi, An. intermedius and An. nuneztovari are necessary to determine their role in malaria transmission in French Guiana.

Key words: An. intermedius - An. nuneztovari - An. oswaldoi - malaria vector - French Guiana

Anopheles darlingi Root is the major vector of human malaria in the Neotropics. In French Guiana, this anopheline species has been considered the sole vector of malaria for more than 50 years because of its high densities, high levels of anthropophilic behaviour and natural infectivity over a wide geographic range (Floch \& Abonnenc 1943b, Mouchet et al. 1989, Claustre et al. 2001). Guianan populations of Anopheles aquasalis and Anopheles triannulatus, both known malaria vectors in South America (de Arruda et al. 1986, de Oliveira-Ferreira et al. 1990, Galardo et al. 2007, Sinka et al. 2010), were also studied by Floch and Abonnenc (1943a, 1944), and the capability of these mosquitoes to transmit Plasmodium parasites was demonstrated. However, no naturally infected specimen of these species was found in French Guiana. Anopheles neivai, another potential vector (Gutierrez et al. 2008), was suspected by Pajot et al. (1978) to transmit malaria in the Upper Oyapock valley based on observations of malaria cases, the high density of this species and the absence of An. darlingi. However, no infected specimens of this species have yet been identified. Therefore, all investigations appeared to confirm that An. darlingi was the only vector of Plasmodium falciparum, Plasmodium vivax and Plasmodium malariae (Mouchet et al. 1989, Claustre et al. 2001, Girod et al. 2008, 2011, Hiwat et al. 2009). However, certain malaria transmission patterns are still far from clear (Carme et al. 2009) and the presence of other anopheline species, such as Anopheles braziliensis, Anopheles intermedius, Anopheles mediopunctatus s.1., Anopheles nuneztovari

+ Corresponding author: idusfour@pasteur-cayenne.fr

Received 22 July 2011

Accepted 14 December 2011 s.1., Anopheles oswaldoi s.1., Anopheles strodei and An. triannulatus s.1., known as primary, secondary or occasional malaria vectors across South America, suggests that other anopheline species may transmit malaria parasites in French Guiana (Panday 1977, de Arruda et al. 1986, Hayes et al. 1987, de Oliveira-Ferreira et al. 1990, Branquinho et al. 1993, Quinones et al. 2006, Galardo et al. 2007). Therefore, the collections performed by our team since 2006 have involved a systematic search for Plasmodium sporozoites in anopheline species. Preliminary results documenting An. intermedius and An. nuneztovari s.l. specimens that were naturally infected by $P$. falciparum have previously been cited in Carme et al. (2009). These findings are strengthened by the data and overall analysis presented here.

From 2006-2011, 11 localities were selected within the framework of various research programmes. The collection sites were distributed along the coastal area, where malaria transmission occurs sporadically and along the Maroni and the Oyapock valleys, where malaria is endemic (Figure). Different protocols were used to collect mosquitoes. Human landing collections (HLC) were performed from 6:00 am-8:00 am and 5:00 pm-7:00 pm (HLC-1), from 5:00 am-7:00 am, 9:00 am-11:00 am, 3:00 pm-5:00 pm and 6:00 pm-10:00 pm (HLC-2) or overnight (HLC-3). Animal bait (AB) was used overnight or during the day. Light traps (LT), LTs plus human bait, Mosquito Magnet (Woodstream Corporation, Lititz, PA, USA) traps and exposure-free bednet traps were used overnight (6:00 pm-6:00 am) (Supplementary data). Collections were made within villages or in the surrounding crop fields and forest. Female anopheline mosquitoes were individually labelled to reflect the site, mode and time of capture. Morphological identification was based on the keys of Shannon (1933), Floch and Abonnenc (1951), Forattini (1962), Faran (1980), Faran and Linthicum (1981), Linthicum (1988) and on unpublished observations from Dr Bruce Harrison to distinguish $A n$. 
intermedius from Anopheles apicimacula. The head and thorax of the anopheline females were tested with enzyme-linked-immunosorbent assays for $P$. falciparum, P. vivax (VK210 and VK247 variant epitopes) and P. $m a-$ lariae circumsporozoite proteins according to Burkot et al. (1984), as modified by Wirtz et al. $(1987,1992)$.

A total of 2,227 anopheline females were assayed for the presence of Plasmodium circumsporozoites. An. darlingi $(\mathrm{n}=929)$ was the most abundant species collected (Table). The other potential malaria vectors found (Supplementary data) were An. oswaldoi s.l. $(\mathrm{n}=483)$, An. intermedius $(\mathrm{n}=246)$, An. braziliensis $(\mathrm{n}=190)$, An. nuneztovari s.l. $(\mathrm{n}=145)$ and An. triannulatus s.l. $(\mathrm{n}=$

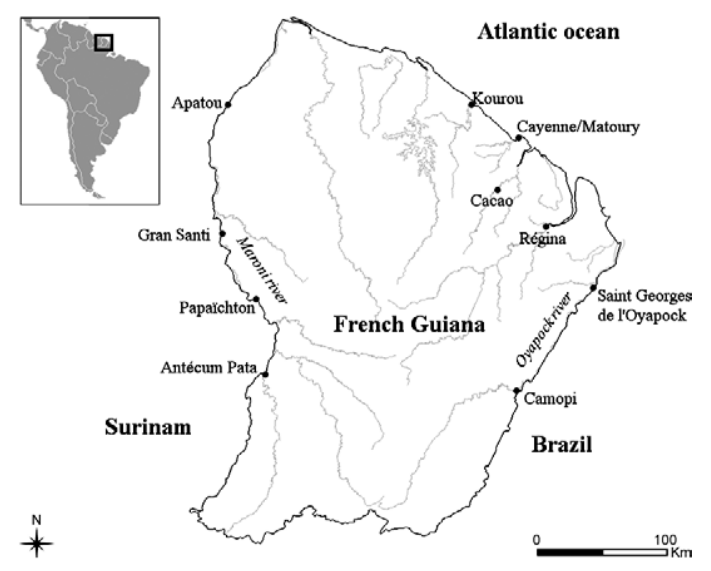

Location of collection sites in French Guiana.
68) (Table I). Two specimens of An. darlingi tested positive for $P$. vivax VK210, corresponding to an infection percentage of $0.22 \%$ (Supplementary data). These two infected females were both collected with the humanlanding method between 6:00 pm-10:00 pm. The first female was captured in a forest camp in the Camopi area on 26 June 2007. The second infected female was caught in a crop field near Saint Georges de l'Oyapock on 5 May 2009. It is especially interesting that three additional highly abundant species tested positive for P. falciparum circumsporozoites: An. oswaldoi s.l. $(\mathrm{n}=1)$, An. intermedius $(\mathrm{n}=3)$ and An. nuneztovari s.l. $(\mathrm{n}=1)$. Based on these results, $0.21 \%$ of $A n$. oswaldoi s.1., $1.22 \%$ of $A n$. intermedius and $0.69 \%$ of An. nuneztovari s.l. specimens collected were infected by P. falciparum. The infected An. oswaldoi s.l. specimen was collected with the Mosquito Magnet ${ }^{\circledR}$ trap in the forest near the village of Camopi. The infected An. nuneztovari s.l. specimen was caught using $\mathrm{AB}$ in the forest near the village of Saint Georges de l'Oyapock. The infected An. intermedius specimens were collected with the human-landing method between 6:00 pm-10:00 pm in the forest near the village of Saint Georges de l'Oyapock $(\mathrm{n}=2)$ and in a crop field near the village of Cacao $(n=1)$. No other mosquito species naturally infected by Plasmodium species were found.

The primary mosquito collection activity since 2006 was conducted in areas in French Guiana where the malaria transmission patterns are variable: along the littoral zone, where malaria cases are sporadic, along the border with Suriname in the Maroni valley, where the number of cases has drastically decreased during the past few years, and along the border with Brazil in the Oyapock valley,

TABLE

List of anopheline females tested for Plasmodium infection, number of specimen tested and number of specimen found infected for Plasmodium falciparum, Plasmodium vivax variant 210, $P$. vivax variant 247 and Plasmodium malariae

\begin{tabular}{|c|c|c|c|c|c|}
\hline Anopheles species & $\mathrm{n}$ & $\begin{array}{c}\text { P. falciparum } \\
\mathrm{n}(\%)\end{array}$ & $\begin{array}{c}\text { P. vivax } 210 \\
\mathrm{n}(\%)\end{array}$ & $\begin{array}{c}\text { P. vivax } 247 \\
\mathrm{n}(\%)\end{array}$ & $\begin{array}{c}\text { P. malariae } \\
\mathrm{n}(\%)\end{array}$ \\
\hline Anopheles darlingi & 929 & - & $2(0.22)$ & - & - \\
\hline Anopheles oswaldoi s.l. & 483 & $1(0.21)$ & - & - & - \\
\hline Anopheles intermedius & 246 & $3(1.22)$ & - & - & - \\
\hline Anopheles braziliensis & 190 & - & - & - & - \\
\hline Anopheles nuneztovari s.l. & 145 & $1(0.69)$ & - & - & - \\
\hline Anopheles triannulatus s.1. & 68 & - & - & - & - \\
\hline Anopheles sp. & 41 & - & - & - & - \\
\hline Anopheles acanthotorynus/nimbus & 42 & - & - & - & - \\
\hline Anopheles mediopunctatus s.1. & 29 & - & - & - & - \\
\hline Anopheles ininii & 19 & - & - & - & - \\
\hline Anopheles aquasalis & 17 & - & - & - & - \\
\hline Anopheles peryassui & 11 & - & - & - & - \\
\hline Anopheles minor & 3 & - & - & - & - \\
\hline Anopheles neivai & 3 & - & - & - & - \\
\hline Anopheles argyritarsis & 1 & - & - & - & - \\
\hline Total & 2,227 & 5 & 2 & - & - \\
\hline
\end{tabular}


where the malaria transmission pattern is still not clear (Carme et al. 2009). The present work confirms (i) the role of An. darlingi as a malaria vector and (ii) the suspected presence of other Anopheles species that are naturally infected by Plasmodium spp in French Guiana.

$A n$. darlingi was the most abundant species of the study. Of the specimens collected, $0.22 \%$ were infected with and could transmit $P$. vivax. This percentage is lower than those obtained for An. intermedius (1.22\%) and An. nuneztovari ( $0.69 \%)$, but does not challenge the status of An. darlingi as the principal malaria vector in French Guiana. Indeed, in many previous studies performed in this region, An. darling $i$ was collected in high densities, had a high sporozoite index and was the only species naturally infected by the four Plasmodium sp. and variants, especially along the border with Suriname in the Maroni valley (Girod et al. 2008, Hiwat et al. 2009, Fouque et al. 2010). In our study, specimens of this species infected by $P$. vivax were found along the Oyapock River, where this parasite causes most cases of malaria (Carme et al. 2009, Girod et al. 2011), whereas the other anophelines carried P. falciparum. Even if our dataset does not furnish conclusive evidence, the documented parasite infections define a pattern in which the status of An. darlingi as the major vector is certain and in which An. intermedius, An. nuneztovari and An. oswaldoi may play local roles in P. falciparum transmission.

It is rare to find and document a naturally infected An. intermedius. de Arruda (1986) found that 3.3\% of the specimens tested contained oocysts in their midguts. Galardo et al. (2007) found the four Plasmodium species and variants in four distinct An. intermedius populations in the neighbouring state of Amapá, Brazil, but observed a low inoculation rate for this species. Even if little is known about the role of An. intermedius in malaria transmission, vigilance has always been required for this vector (dos Santos et al. 2005, Sinka et al. 2010). Our study found An. intermedius specimens that were naturally infected by P. falciparum in Saint Georges de l'Oyapock, at the Brazilian border. However, no study has yet demonstrated a role for this mosquito species in malaria transmission. In addition, this species is often described as exophilic or zoophilic and is found in sylvatic or perisylvatic environments (Forattini 1962, Zimmerman et al. 2006, Galardo et al. 2007). It is probable that contact between this species and humans is occasional and could occur in households or camps near the forest. An. oswaldoi s.l. has been identified as a secondary or local vector in many areas of South America (Hayes et al. 1987, Branquinho et al. 1993, Mouchet et al. 2004, Quinones et al. 2006, Sinka et al. 2010). The species complex includes at least four species (Marrelli et al. 1999) that can transmit $P$. falciparum, $P$. vivax variants and $P$. malariae (Hayes et al. 1987, Branquinho et al. 1993, Quinones et al. 2006). The biting behaviour of these mosquitoes is often described as exophilic and zoophilic. In this study, we found one specimen that was naturally infected with P. falciparum in a forested area near Camopi. However, we did not identify the species within the complex and the behavioural patterns of this species remain unknown. An. nuneztovari s.l. is described as a primary or secondary vector (Hayes et al. 1987, Tadei \& Thatcher 2000, Mouchet et al. 2004, Quinones et al. 2006, Moreno et al. 2007, Sinka et al. 2010). Heterogeneous behaviours and variable vectorial capacities throughout the distribution of this mosquito taxon may be explained by the presence of a complex of species (Sinka et al. 2010), in which five genetic lineages are currently identified (Mirabello \& Conn 2008). We did not identify species within the An. oswaldoi s.l. complex and the behavioural patterns of this group remain unknown. Based on the literature, we can hypothesise that the populations from French Guiana resemble those from Brazil and Suriname. Exophilic, exophagic and zoophilic behaviours have been observed in this region of South America (Panday 1977, Montoya-Lerma et al. 2011), whereas anthropophilic and endophagic behaviours are commonly found in Peru, Colombia and Venezuela (Montoya-Lerma et al. 2011). In addition, Mirabello and Conn (2008) identified lineage 1 in northeastern and central Amazonia, including the Guiana shield. In French Guiana, data on An. intermedius, An. oswaldoi s.l. and An. nuneztovari s.l. are still scarce. Further insights on the behaviour, ecology and genetics of these species are needed to confirm the roles that the species play in malaria transmission.

In addition to the present work, studies on other species known to be possible vectors in neighbouring countries (e.g., An. triannulatus s.l. or An. aquasalis) would complement the approach taken by our research (Charlwood \& Wilkes 1981, Rubio-Palis 1994, Galardo et al. 2007, Sinka et al. 2010). Mosquito collections performed in the inland part of French Guiana would serve to complete the Anopheles species list in French Guiana. Indeed, it is surprising that species known as malaria vectors in the Brazilian Amazon and Suriname (e.g., the Albitarsis complex) have not yet been encountered in French Guiana.

\section{ACKNOWLEDGEMENTS}

To Dr RE Harbach, Dr B Harrison, Dr RC Wilkerson and Prof MAM Sallum, for providing help to clearly assess the identification of An. intermedius, and to Sarah C Chaney, for proofreading the paper.

\section{REFERENCES}

Branquinho MS, Lagos CB, Rocha RM, Natal D, Barata JM, Cochrane AH, Nardin E, Nussenzweig RS, Kloetzel JK 1993. Anophelines in the state of Acre, Brazil, infected with Plasmodium falciparum, $P$. vivax, the variant $P$. vivax $\mathrm{VK} 247$ and $P$. malariae. Trans $R$ Soc Trop Med Hyg 87: 391-394.

Burkot TR, Williams JL, Schneider I 1984. Identification of Plasmodium falciparum-infected mosquitoes by a double antibody enzymelinked immunosorbent assay. Am J Trop Med Hyg 33: 783-788.

Carme B, Ardillon V, Girod R, Grenier C, Joubert M, Djossou F, Ravachol F 2009. Update on the epidemiology of malaria in French Guiana. Med Trop 69: 19-25.

Charlwood JD, Wilkes TJ 1981. Observations on the biting activity of Anopheles triannulatus bachmanni from Mato Grosso, Brazil. Acta Amazonica 11: 411-441.

Claustre J, Venturin C, Nadire M, Fauran P 2001. Malarial vectors in French Guiana: study in an epidemic focus near Cayenne (19891998). Bull Soc Pathol Exot 94: 353-357.

de Arruda M, Carvalho MB, Nussenzweig RS, Maracic M, Ferreira AW, Cochrane AH 1986. Potential vectors of malaria and their 
different susceptibility to Plasmodium falciparum and Plasmodium vivax in northern Brazil identified by immunoassay. Am J Trop Med Hyg 35: 873-881.

de Oliveira-Ferreira J, Lourenço-de-Oliveira R, Teva A, Deane LM, Daniel-Ribeiro CT 1990. Natural malaria infections in anophelines in Rondônia state, Brazilian Amazon. Am J Trop Med Hyg 43: 6-10.

dos Santos JM, Rodriguez GA, Maia J de F, Tadei WP 2005. Variability and genetic differentiation among Anopheles (Ano.) intermedius Chagas, 1908 and Anopheles (Ano.) mattogrossensis Lutz \& Neiva, 1911 (Diptera: Culicidae) from the Brazilian Amazon. Mem Inst Oswaldo Cruz 100: 531-537.

Faran ME 1980. Mosquito studies (Diptera: Culicidae): a revision of the Albimanus Section of the subgenus Nyssorhynchus of Anopheles. Contrib Am Entomol Inst 15: 1-215.

Faran ME, Linthicum KJ 1981. A handbook of the Amazonian species of Anopheles (Nyssorhynchus) (Diptera: Culicidae). Mosq Syst 13: 1-81.

Floch H, Abonnenc E 1943a. A. aquasalis Curry 1932 et paludisme en Guyane Française. Infection naturelle et infection experimentale. In Institut Pasteur de la Guyane et du Territoire de l'Inini, Institut Pasteur de la Guyane et du Territoire de l'Inini, Cayenne, p. 8.

Floch H, Abonnenc E 1943b. Sur le rôle de A. darlingi Root 1926 dans la transmission du paludisme en Guyane Française. In Institut Pasteur de la Guyane et du Territoire de l'Inini, Institut Pasteur de la Guyane et du Territoire de l'Inini, Cayenne, p. 10.

Floch H, Abonnenc E 1944. A. triannulatus Neiva \& Pinto en Guyane Française. Morphologie des oeufs et infection expérimentale par $P$. falciparum et $P$. vivax. In Institut Pasteur de la Guyane et du Territoire de l'Inini, Institut Pasteur de la Guyane et du Territoire de l'Inini, Cayenne, p. 7.

Floch H, Abonnenc E 1951. Anophèles de la Guyane Française. Arch Inst Pasteur Guyane Terr Inini 236: 1-92.

Forattini OP 1962. Entomologia médica, Vol. 1, Faculdade de Saúde Pública da Universidade de São Paulo, São Paulo, 662 pp.

Fouque F, Gaborit P, Carinci R, Issaly J, Girod R 2010. Annual variations in the number of malaria cases related to two different patterns of Anopheles darlingi transmission potential in the Maroni area of French Guiana. Malar J 9: 80.

Galardo AK, Arruda M, D’Almeida Couto AA, Wirtz R, Lounibos LP, Zimmerman RH 2007. Malaria vector incrimination in three rural riverine villages in the Brazilian Amazon. Am J Trop Med Hyg 76: 461-469.

Girod R, Gaborit P, Carinci R, Issaly J, Fouque F 2008. Anopheles darlingi bionomics and transmission of Plasmodium falciparum, Plasmodium vivax and Plasmodium malariae in Amerindian villages of the Upper-Maroni Amazonian forest, French Guiana. Mem Inst Oswaldo Cruz 103: 702-710.

Girod R, Roux E, Berger F, Stefani A, Gaborit P, Carinci R, Issaly J, Carme B, Dusfour I 2011. Unravelling the relationships between Anopheles darlingi (Diptera: Culicidae) densities, environmental factors and malaria incidence: understanding the variable patterns of malarial transmission in French Guiana (South America). Ann Trop Med Parasitol 105: 107-122.

Gutierrez LA, Naranjo N, Jaramillo LM, Muskus C, Luckhart S, Conn JE, Correa MM 2008. Natural infectivity of Anopheles species from the Pacific and Atlantic regions of Colombia. Acta Trop 107: 99-105.

Hayes J, Calderon G, Falcon R, Zambrano V 1987. Newly incriminated anopheline vectors of human malaria parasites in Junin department, Peru. J Am Mosq Control Assoc 3: 418-422.

Hiwat H, Issaly J, Gaborit P, Somai A, Samjhawan A, Sardjoe P, Soekhoe T, Girod R 2009. Behavioral heterogeneity of Anopheles darlingi (Diptera: Culicidae) and malaria transmission dynamics along the Maroni River, Suriname, French Guiana. Trans $R$ Soc Trop Med Hyg 104: 207-213.

Linthicum KJ 1988. A revision of the Argyritarsis Section of the subgenus Nyssorhynchus of Anopheles (Diptera: Culicidae). Mosq Syst 20: 98-271.

Marrelli MT, Malafronte RS, Flores-Mendoza C, Lourenço-de-Oliveira R, Kloetzel JK, Marinotti O 1999. Sequence analysis of the second internal transcribed spacer of ribosomal DNA in Anopheles oswaldoi (Diptera: Culicidae). J Med Entomol 36: 679-684.

Mirabello L, Conn JE 2008. Population analysis using the nuclear white gene detects Pliocene/Pleistocene lineage divergence within Anopheles nuneztovari in South America. Med Vet Entomol 22: 109-119.

Montoya-Lerma J, Solarte YA, Giraldo-Calderón GI, Quiñones ML, Ruiz-López F, Wilkerson RC, González R 2011. Malaria vector species in Colombia - A Review. Mem Inst Oswaldo Cruz 106 (Suppl. I): 223-238.

Moreno JE, Rubio-Palis Y, Paez E, Perez E, Sanchez V 2007. Abundance, biting behaviour and parous rate of anopheline mosquito species in relation to malaria incidence in gold-mining areas of southern Venezuela. Med Vet Entomol 21: 339-349.

Mouchet J, Carnevale P, Coosemans M, Julvez J, Manguin S, Richard-Lenoble D, Sircoulon J 2004. Biodiversité du paludisme dans le monde, John Libbey, Eurotext, Paris, 428 pp.

Mouchet J, Nadire-Galliot M, Gay F, Poman JP, Lepelletier L, Claustre J, Bellony S 1989. Malaria in Guiana. II. The characteristics of different foci and antimalarial control. Bull Soc Pathol Exot Filiales 82: 393-405.

Pajot FX, Molez JF, Le Pont F 1978. Anophèles et paludisme sur le Haut-Oyapock (Guyanne Française)]. Cahiers de l'ORSTOM series entomologie médicale et Parasitologie XVI: 105-111.

Panday SR 1977. Anopheles nuneztovari and malaria transmission in Surinam. Mosq Syst 37: 728-737.

Quinones ML, Ruiz F, Calle DA, Harbach RE, Erazo HF, Linton YM 2006. Incrimination of Anopheles (Nyssorhynchus) rangeli and An. (Nys.) oswaldoi as natural vectors of Plasmodium vivax in Southern Colombia. Mem Inst Oswaldo Cruz 101: 617-623.

Rubio-Palis Y 1994. Variation of the vectorial capacity of some anophelines in western Venezuela. Am J Trop Med Hyg 50: 420-424.

Shannon RC 1933. Anophelines of the Amazon Valley. Proceedings of the Entomological Society of Washington 35: 117-143.

Sinka ME, Rubio-Palis Y, Manguin S, Patil AP, Temperley WH, Gething PW, Van Boeckel T, Kabaria CW, Harbach RE, Hay SI 2010. The dominant Anopheles vectors of human malaria in the Americas: occurrence data, distribution maps and bionomic precis. Parasit Vectors 3: 72.

Tadei WP, Thatcher BD 2000. Malaria vectors in the Brazilian Amazon: Anopheles of the subgenus Nyssorhynchus. Rev Inst Med Trop Sao Paulo 42: 87-94.

Wirtz RA, Burkot TR, Graves PM, Andre RG 1987. Field evaluation of enzyme-linked immunosorbent assays for Plasmodium falciparum and Plasmodium vivax sporozoites in mosquitoes (Diptera: Culicidae) from Papua New Guinea. J Med Entomol 24: 433-437.

Wirtz RA, Sattabongkot J, Hall T, Burkot TR, Rosenberg R 1992. Development and evaluation of an enzyme-linked immunosorbent assay for Plasmodium vivax-VK247 sporozoites. J Med Entomol 29: 854-857.

Zimmerman RH, Galardo AK, Lounibos LP, Arruda M, Wirtz R 2006. Bloodmeal hosts of Anopheles species (Diptera: Culicidae) in a malaria-endemic area of the Brazilian Amazon. J Med Entomol 43: 947-956. 
Localities, year, dates and methods of mosquito collections

\begin{tabular}{|c|c|c|c|}
\hline Locality & Year & $\begin{array}{c}\text { Date } \\
\text { (day month) }\end{array}$ & Collection method \\
\hline Antécum Pata & 2007 & 1-3 June & HLC-3 \\
\hline Apatou & 2007 & 31 May-1 June & HLC-3 \\
\hline Cacao & $\begin{array}{l}2007 \\
2008\end{array}$ & $\begin{array}{l}\text { 26-30 November, } \\
\text { 10-14 December } \\
\text { 25-29 February, } \\
\text { 8-12 September }\end{array}$ & $\begin{array}{c}\text { HLC-2, LT } \\
\text { HLC-2, LT, LT-HB }\end{array}$ \\
\hline Camopi & $\begin{array}{l}2007 \\
2008\end{array}$ & $\begin{array}{l}\text { 18-29 June } \\
\text { 15-17 January } \\
\text { 12-16 May, } \\
\text { 7-11 July } \\
\text { 15-19 December } \\
\text { 5-9 January } \\
\text { 11-14 June }\end{array}$ & $\begin{array}{c}\text { HLC-2, LT } \\
\text { HLC-3 } \\
\text { HLC-3, LT, EFT, MM, LT-HB } \\
\text { HLC-2, LT } \\
\text { HLC-2, LT } \\
\text { HLC-3, LT, EFT, MM }\end{array}$ \\
\hline Cayenne & $\begin{array}{l}2006 \\
2007\end{array}$ & $\begin{array}{l}\text { 9-12 October, } \\
\text { 23-26 October } \\
\text { 21-24 May, } \\
\text { 11-14 June }\end{array}$ & $\begin{array}{l}\text { HLC-1, AB, LT } \\
\text { HLC-1, AB, LT }\end{array}$ \\
\hline Gran Santi & $\begin{array}{l}2007 \\
2008\end{array}$ & $\begin{array}{l}\text { 3-13 July } \\
\text { 21-25 July, } \\
\text { 4-8 August }\end{array}$ & $\begin{array}{l}\text { HLC-2, LT } \\
\text { HLC-2, LT }\end{array}$ \\
\hline Kourou & $\begin{array}{l}2010 \\
2011\end{array}$ & $\begin{array}{l}\text { 8-11 February, } \\
\text { 22-25 March } \\
\text { 14-17 February }\end{array}$ & $\begin{array}{l}\text { HLC-2C, LT } \\
\text { HLC-2C, LT }\end{array}$ \\
\hline Matoury & $\begin{array}{l}2010 \\
2011\end{array}$ & $\begin{array}{l}\text { 8-11 March, } \\
\text { 6-9 April } \\
\text { 28-31 March }\end{array}$ & $\begin{array}{l}\text { HLC-2, LT } \\
\text { HLC-2, LT }\end{array}$ \\
\hline Papaïchton & 2007 & 3-5 June & HLC-3 \\
\hline Régina & $\begin{array}{l}2009 \\
2010 \\
2011\end{array}$ & $\begin{array}{c}\text { 4-5 June } \\
\text { 22-25 February, } \\
\text { 19-22 April } \\
\text { 14-17 March }\end{array}$ & $\begin{array}{c}\text { HLC-3, LT, EFT, LT-HB } \\
\text { HLC-2, LT } \\
\text { HLC-2, LT }\end{array}$ \\
\hline \multirow[t]{3}{*}{$\begin{array}{l}\text { Saint Georges } \\
\text { de l'Oyapock }\end{array}$} & 2006 & $\begin{array}{l}\text { 6-10 November } \\
\text { 20-23 November, } \\
\text { 4-7 December } \\
\text { 9-12 May, }\end{array}$ & $\begin{array}{c}\text { HLC-3, LT } \\
\text { HLC-1, AB, LT } \\
\text { HLC-1, AB, LT }\end{array}$ \\
\hline & 2009 & $\begin{array}{l}\text { 23-26 July } \\
\text { 20-23 April, } \\
\text { 4-7 May }\end{array}$ & HLC-2, LT \\
\hline & & 2-4 June & HLC-3, LT, EFT, LT-HB \\
\hline
\end{tabular}

AB: overnight and day animal baits; EFT: overnight exposure-free bednet trap; HLC-1: human landing collections in the range of 06:00 am-08:00 am and 05:00 pm-07:00 pm; HLC-2: in the range of 05:00 am-07:00 am, 09:00 am-11:00 am, 03:00 pm05:00 pm and 06:00 pm-10:00 pm; HLC-3: overnight; LT: overnight light-trap; LT-HB: overnight LT plus human bait; MM: overnight Mosquito Magnet ${ }^{\mathbb{Q}}$. 